\title{
Characteristics of two mesoscale convective systems (MCSs) over the Greater Jakarta: case of heavy rainfall period 15-18 January 2013
}

\author{
Danang Eko Nuryanto ${ }^{1,2^{*}} \mathbb{D}$, Hidayat Pawitan ${ }^{1}$, Rahmat Hidayat ${ }^{1}$ and Edvin Aldrian ${ }^{3}$
}

\begin{abstract}
Two different mesoscale convective system (MCS) events that produced the heavy rainfall over the Greater Jakarta (GJ) during 15-18 January 2013 period were investigated. The purpose of the present study is to analyze the atmospheric conditions of two different MCSs during the heavy rainfall. Data consist of 3 hourly rainfalls of meteorological stations, infrared satellite, sounding, 6-hourly surface wind and reanalysis data. The first MCS was developed at 16:00 LT on 14 January 2013 over the eastern coast of Sumatra covered an area of $249,732 \mathrm{~km}^{2}$ at maximum size, with about $16 \mathrm{~h}$ durations. The next MCS was developed at 22:00 LT on 16 January 2013 over the northern coast of the GJ in $9 \mathrm{~h}$ of duration, and maximum covered area around $55,829 \mathrm{~km}^{2}$. A warmer and moist air was observed on the low-level layer in the evening of 16 January 2013 (prior of second MCS), in comparison to 14 January 2013 event. Combination of both the surface strong wind perturbation and equivalent potential temperature in the second MCS might be contributed to heavy rainfall over the GJ than the first one.
\end{abstract}

Keywords: Equivalent potential temperature, Heavy rainfall, Mesoscale convective system, Greater Jakarta

\section{Introduction}

The Greater Jakarta (GJ) is a generic term for the urban agglomeration surrounding Jakarta, with an administrative definition cover Jakarta, Bogor, Depok, Tangerang, Bekasi, known locally as the "Jabodetabek". Jakarta is the capital and the largest city in Indonesia, located on the northwest coast of Java, the most populated island and most important industrial and agricultural region since the colonial era. Furthermore, Bogor, Depok, Tangerang and Bekasi refer to the built-up areas around Jakarta (Fig. 1). As part of Indonesia Maritime Continent (IMC), the GJ area is located in the tropical monsoon climate zone that is characterized as a hot and humid place due to its location close to the equator and it is classified dominantly as monsoon season, so the city has distinct wet and dry seasons. These seasonal circulation features are

\footnotetext{
*Correspondence: danang.eko@bmkg.go.id

${ }^{2}$ Research and Development Center, Indonesian Agency for Meteorology Climatology and Geophysics, Jl. Angkasa I No. 2 Lt. 8, Kemayoran, Jakarta Pusat 10720, Indonesia

Full list of author information is available at the end of the article
}

clearly recognized in the annual cycle of observed Jakarta rainfall in history data where rainfall reaches monthly average values above $150 \mathrm{~mm}$ in December-March, and below $100 \mathrm{~mm}$ during June to September (Siswanto et al. 2015).

In the period 15-18 January 2013, the GJ experienced flood event that was caused by heavy rains and river flows. The same event was first reported by $\mathrm{Wu}$ et al. (2013). The event had a negative impact on public health (i.e., increased rates of diarrhea, respiratory infections, hepatitis A and E, typhoid fever, leptospirosis, and diseases borne by insects) and significant economic losses. The National Agency for Disaster Management (BNPB) reported that about 500,000 houses were inundated in the event (source data: http://dibi.bnpb.go.id). Most observation sites within the GJ recorded an accumulated rainfall of more than $300 \mathrm{~mm}$ for these 4 days.

The previous studies revealed a crucial factor generating heavy rainfall over the GJ, i.e., a strong and persistent trans-equatorial monsoonal flow from the Northern Hemisphere (Wu et al. 2007; Trilaksono et al. 2011, 2012; Siswanto et al. 2015), a strong and coherent 


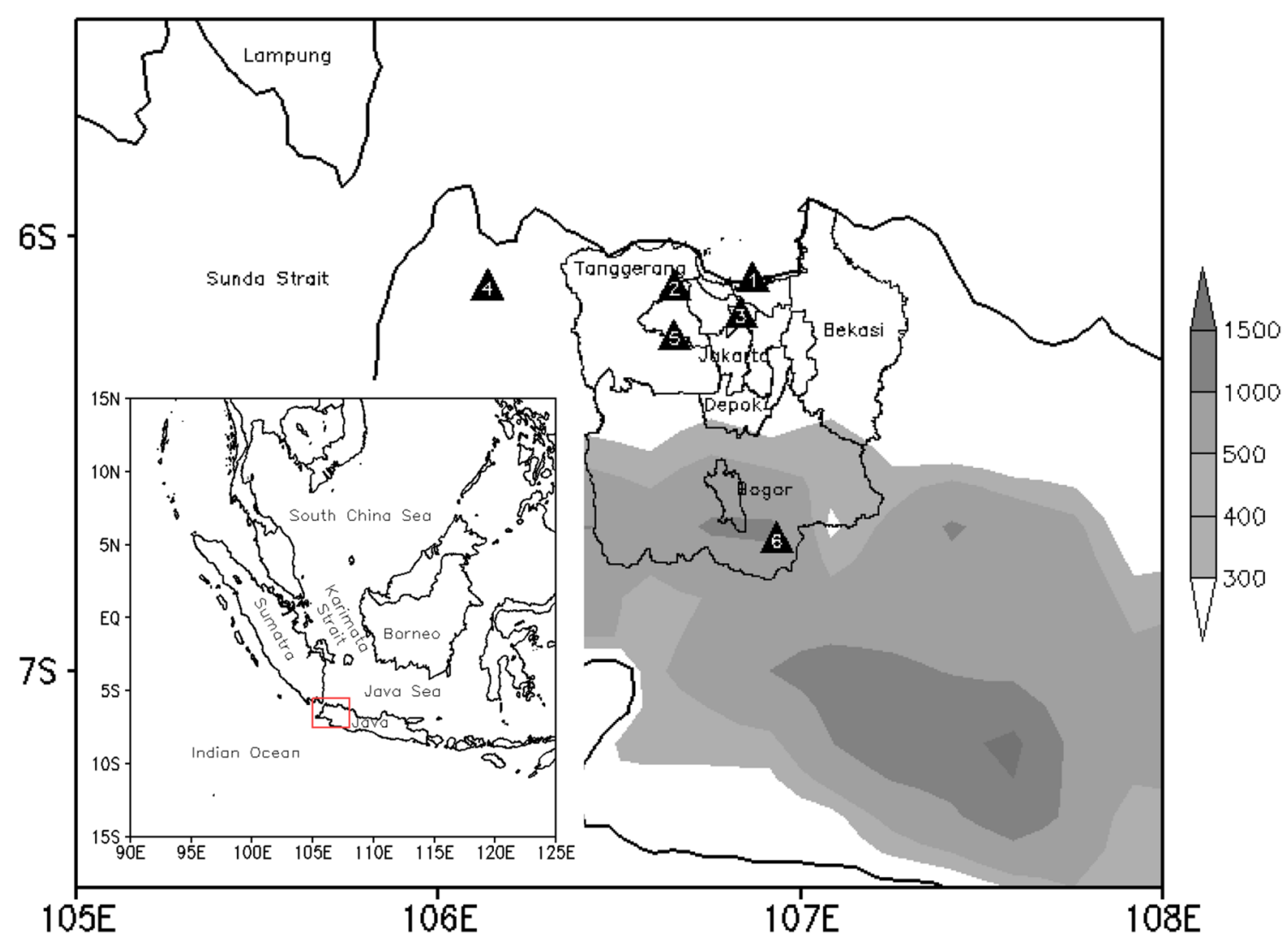

Fig. 1 Area study of the Greater Jakarta as part of Indonesian Maritime Continent. The center of the region is the Greater Jakarta. The numbered triangles are the meteorological stations used in the study, i.e., (1) Port of Tanjung Priok, (2) Soekarno-Hatta Airport Cengkareng, (3) Jakarta Observatory Kemayoran, (4) Serang, (5) Budiarto Airport Curug Tangerang and (6) Citeko Bogor. The shading shows elevations higher than $300 \mathrm{~m}$

Madden-Julian Oscillation (MJO) activity (Hidayat and Kizu 2010; Hattori et al. 2011; Wu et al. 2013), and also intensive low-level wind convergence around the GJ (Wu et al. 2013). Under these particular atmospheric conditions, convective clouds developed at greater height, which favorable for the occurrence of heavy rainfall over the study area.

As one form of convective clouds, mesoscale convective systems (MCSs) are responsible for most of the heavy rainfall events (Doswell et al. 1996; Choi et al. 2011; Jeong et al. 2016). The MCS is a cloud system that is associated with a complex of convective system and produces an adjacent rainfall area about $100 \mathrm{~km}$ in at least one direction in horizontal scale (Houze 2014). Therefore, a systematized group of convective cloud elements whose life cycle longer than the individual convective element (greater than $3 \mathrm{~h}$ ), indicated as an MCS.

A number of studies on MCS have been widely taken in the tropics (e.g., Mohr and Zipser 1996; Zolman and Zipser 2000; Yuan and Houze 2010; Virts and Houze 2015; Putri et al. 2017, 2018). However, research on MCS in IMC is still very limited, i.e., the general life cycle of
MCS in IMC (Putri et al. 2017) and the certain cases of MCS events in Sumatra and Java (Putri et al. 2018) using satellite data. Recently, the preliminary study of propagation (Nuryanto et al. 2017b); kinematic and thermodynamic structures (Nuryanto et al. 2018) of MCS corresponding to the heavy rainfall event at GJ had been proposed; however, the MCS feature during heavy rainfall events in IMC is not clear. Therefore, it is vigorous to have a better understanding of MCS during heavy rainfall of the equatorial atmospheric conditions over IMC, especially the GJ area.

In this paper, we address the influence of atmospheric conditions on two different MCS events, its life cycle, and related maturity processes of MCS supporting heavy rainfall over the GJ area. The evidence of MCS events that occurred in the GJ area on January 2013 was investigated using modified "Grab 'em, Tag 'em, Graph 'em" (GTG) algorithm (Whitehall et al. 2015; Nuryanto et al. 2017a; Putri et al. 2017, 2018). A construction theory from the documented previous studies and further investigation of certain atmospheric condition analysis during the MCS events are presented. "Data and methodology" 
section describes the detailed data and methodology. The following section discusses the results, and conclusions are drawn in the subsequent section.

\section{Data and methodology}

Data used in the present study are obtained from a variety of observational and model-based datasets. The six observational stations by the Indonesian Agency for Meteorology Climatology and Geophysics (BMKG) around the GJ area are: (1) Port of Tanjung Priok $\left(106.867^{\circ} \mathrm{E} ; 6.100^{\circ} \mathrm{S}\right)$, (2) Soekarno-Hatta Airport Cengkareng $\left(106.650^{\circ} \mathrm{E} ; 6.117^{\circ} \mathrm{S}\right)$, (3) Jakarta Observatory Kemayoran $\left(106.583^{\circ} \mathrm{E} ; 6.183^{\circ} \mathrm{S}\right)$, (4) Serang $\left(106.133^{\circ} \mathrm{E}\right.$; $6.117^{\circ} \mathrm{S}$ ), (5) Budiarto Airport Curug Tangerang $\left(106.650^{\circ} \mathrm{E}\right.$; $\left.6.233^{\circ} \mathrm{S}\right)$, and (6) Citeko Bogor $\left(106.933^{\circ} \mathrm{E}\right.$; $\left.6.700^{\circ} \mathrm{S}\right)$ that located in Fig. 1. The rainfall data are also available in the previous papers (Nuryanto et al. 2017a, b, 2018) except in Wu et al. (2013). The 3 hourly rainfall data are analyzed to investigate the time series and the accumulated amount of rainfall due to heavy rainfall.

To reveal the features of the interior structure and movement in MCSs, high-resolution datasets are essential. Moreover, radar data provide datasets with high spatial and temporal resolutions of the internal structure of precipitation. There have already been several studies on convective clouds over IMC using also radars (which is necessary to study precipitation), i.e., Sumatera (Sakurai et al. 2005; Kawashima et al. 2011) and GJ area (Wu et al. 2007, 2013; Mori et al. 2018). We employed a C-band Doppler radar (CDR) installed at Soekarno-Hatta International Airport Cengkareng (denote by number 2 in Fig. 1), $21 \mathrm{~m}$ above mean sea level (AMSL), to observe the behaviors of convections over the GJ, with high temporal resolutions. The CDR instrument in this study was different location with Wu et al. (2013) that give support the explanation. They have implemented meteorological radar observations continuously at Serpong in the suburbs of Jakarta utilizing a CDR that shows the reflectivity Constant Altitude Plan Position Indicator (CAPPI) at $2.0 \mathrm{~km}$ altitude for 15-17 January 2013. Major specifications of the CDR in this study are summarized in Table 1. Unfortunately, there is no radar data at 20:00 LT-23:00 LT January 15 and 03:00 LT-13:00 LT, January 17, 2013 (see shaded area in Fig. 2). Therefore, it cannot compare to the radar reflectivity structure during the mature stage. This is one reason why we do not use radar data to deep analyze as done by previous studies (Wu et al. 2007, 2013; Mori et al. 2018).

The convection distribution that associated with rainfall events is extracted from the equivalent temperature black body (TBB) of cloud top temperature derived from the Multi-functional Transport Satellite (MTSAT)-IR imagery (http://database.rish.kyoto-u.ac.
Table 1 Specifications of Soekarno-Hatta Airport Cengkareng CDR

\begin{tabular}{ll}
\hline Parameter & Value \\
\hline Band & C-Band \\
Beam width & $<1^{\circ}$ \\
Frequency & $5.6 \mathrm{GHz}$ \\
Pulse width & $0.5 ; 0.8 ; 1.0 ; 2 \mu \mathrm{s}$ \\
Minimum PRF & $250 \mathrm{~Hz}$ \\
Maximum PRF & $1250 \mathrm{~Hz}$ \\
Signal Processor & EDRP 9 \\
TXType & Magnetron \\
Power & $250 \mathrm{KW}$ \\
RXType & Stallo \\
Polarization & Single \\
Manufacture & EEC \\
Lowest angle & $0.9^{\circ}$ \\
Highest angle & $100^{\circ}$ \\
Task cycle time min & 10 \\
Task cycle time max & 10 \\
MDS & -31 \\
\hline
\end{tabular}

jp/arch/ctop/index_e.html) from Research Institute for Sustainable Humanosphere (RISH) database of Kyoto University (Hamada and Nishi 2010). MTSAT satellite imagery with IR1 channel with a wavelength of $11 \mu \mathrm{m}$ which shows the surface temperature of the land, sea level or cloud top above it. The data used have a spatial resolution of $0.08^{\circ}$ and an hourly temporal resolution. The cross-calibrated multi-platform (CCMP) surface wind data, which cover the global surface wind with 6-hourly temporal resolution and $0.25^{\circ}$ spatial resolution (Atlas et al. 2011) are used to identify the cloudinduced surface flows. The vertical upper-air data from atmospheric soundings performed twice a day at Cengkareng are used to analyze the atmospheric vertical profile during MCS events. There are no data at 07:00 LT 15 January 2013 and 07:00 LT 17 January 2013. In this study, we show the features of atmospheric conditions prior to MCSs event. To get another perspective with Nuryanto et al. (2018), the potential temperature (theta), mixing ratio, equivalent potential temperature (theta-e), and horizontal wind speed values were extracted from the sounding data to study the vertical structures of the MCSs.

The mesoscale charts were generated using the Japanese Reanalysis 55 Years (JRA-55), which are available at 6-hourly intervals with $1.25^{\circ}$ horizontal resolution (Kobayashi et al. 2015; Harada et al. 2016), which is denser than other reanalysis data, such as NCEP/NCAR, JRA25, and CFSR, except ERA-Interim has the highest resolution among the raised reanalysis datasets. According to 


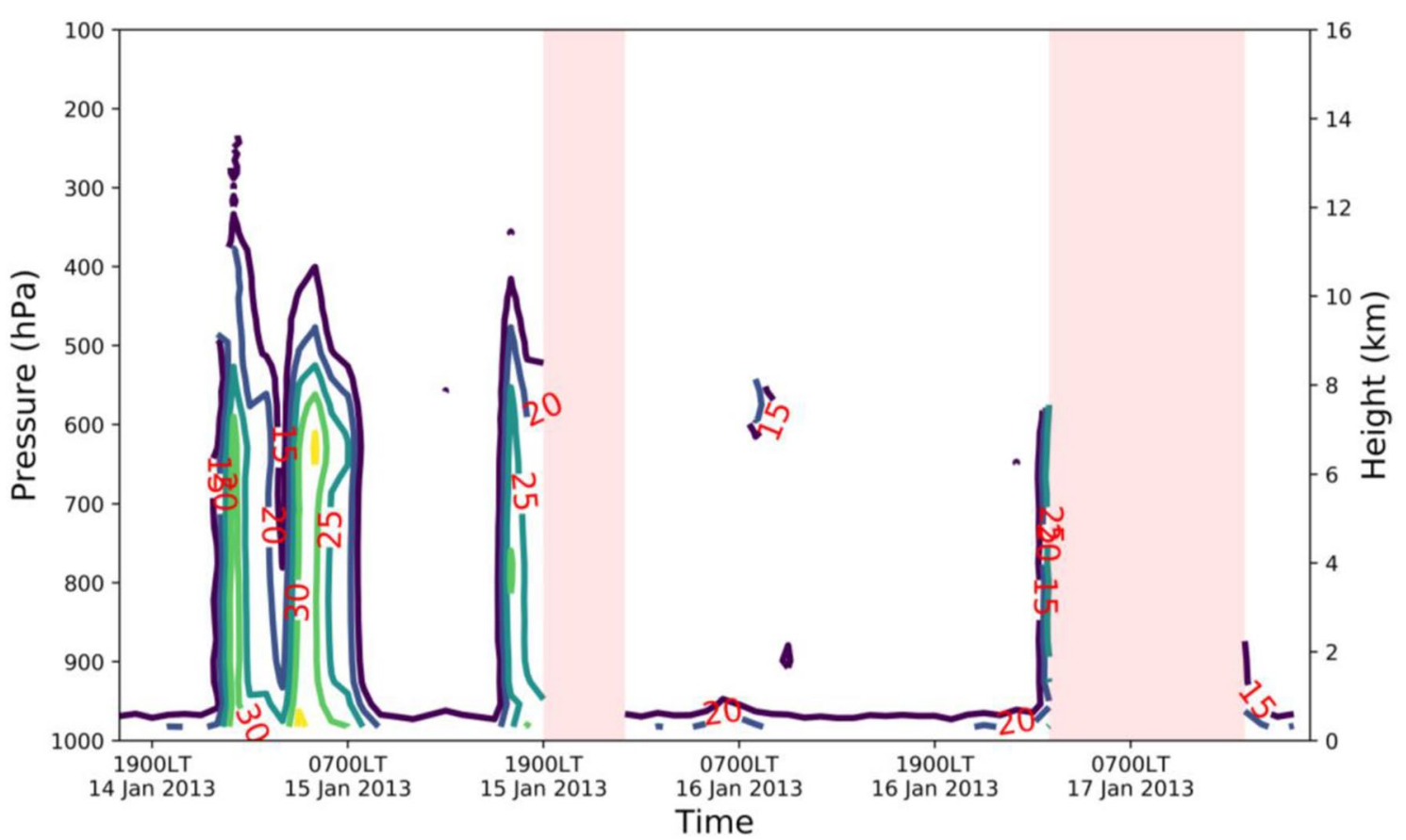

Fig. 2 Time-series of radar reflectivity average at area $6.1^{\circ} \mathrm{S}-6.35^{\circ} \mathrm{S}$ and $106.7^{\circ} \mathrm{E}-107.0^{\circ} \mathrm{E}$ during $14-17$ January 2013 . Horizontal label is hour (top) and date (bottom). Shaded area indicates no data

Harada et al. (2016), the JRA-55 has higher quality in the representation of daily precipitation in the tropics.

The method for identifying MCS in this study is a modified GTG algorithm (Whitehall et al. 2015). Application of the GTG algorithm is a new method which has been used in the earlier studies (Nuryanto et al. 2017a; Putri et al. 2017, 2018), and have the advantage of anticipating a problem relating to the complex life cycle of the MCSs (Whitehall et al. 2015), such as the merging of multiple convective cells as identifying by Mathon et al. (2002). The procedure is based on TBB data as input, where MCSs are identified based on a set of modified criteria as in Table 2. The GTG algorithm in this paper implements the MCS criteria such as an area covered $10,000 \mathrm{~km}^{2}$ at minima where $\mathrm{TBB} \leq 221 \mathrm{~K}$

Table 2 Modified specific identification of MCS used in this study

\begin{tabular}{ll}
\hline Physical characteristics \\
\hline TBB temperature & $\leq 221 \mathrm{~K}$ \\
Size & $\geq 10,000 \mathrm{~km}^{2}$ \\
Initiation & Size and temperature thresholds are first met \\
$\begin{array}{l}\text { Termination } \\
\text { Duration }\end{array}$ & $\begin{array}{c}\text { Size and temperature definition are last satisfied } \\
\text { period } \geq 3 \mathrm{~h}\end{array}$ \\
Mature & $\begin{array}{c}\text { Minimum mean of cloud temperature definition must } \\
\text { be met }\end{array}$ \\
&
\end{tabular}

and there exists a convective core with at least $10 \mathrm{~K}$ of TBB range. These MCS criteria are different with Maddox (1980) to gain the new finding of tropical region, especially the GJ area.

To analyze the behavior of MCSs, we composite the significant TBB for each case. The composite technique allows us to cover the recurrent selection of infrared imagery that is taken during heavy rainfalls and the average of each TBB for the time selected. For each MCS event, we applied composites of TBB data for every 3-h $(\mathrm{LT}=\mathrm{UTC}+7)$ along the heavy rainfall events. To identify the cloud-induced surface flows, wind vector perturbations were calculated by subtracting an actual wind from the 6-hourly averaged winds for 14-19 January 2013.

\section{Results and discussion Heavy rainfall}

Figure 3 shows rainfall variations observed at the six weather stations of BMKG around the GJ during 15-18 January 2013. The rainfall patterns show the similarity of patterns to radar reflectivity (Fig. 2). There are two peaks of mean curve rainfalls which reach more than $30 \mathrm{~mm} / 3 \mathrm{~h}$ in the morning of 15 and 17 January 2013, however, the rest peaks measure less than $30 \mathrm{~mm}$, i.e., in the evening of January 15 th, January 16 th afternoon, and in the early morning of 18 January 2013. The 
distribution of early morning rainfalls for six weather stations during these two peaks of rainfall was higher with more than $60 \mathrm{~mm}$, namely about $67.8 \mathrm{~mm}$ and $106.8 \mathrm{~mm}$ (Table 3 ) on January 15th and 17th, respectively. The highest 3 hourly rainfall on 17 January 2013 (08:00-10:00 LT) recorded $147 \mathrm{~mm}$ at Kemayoran (Fig. 3). The high daily rainfalls at Kemayoran, Cengkareng and Tanjung Priok on 17 January 2013 recorded $193 \mathrm{~mm}, 133 \mathrm{~mm}$ and $119 \mathrm{~mm}$, respectively. There is a plenty of evidence to show that heavy rainfall events during this period are measured at most stations which mean felt in the large regions.

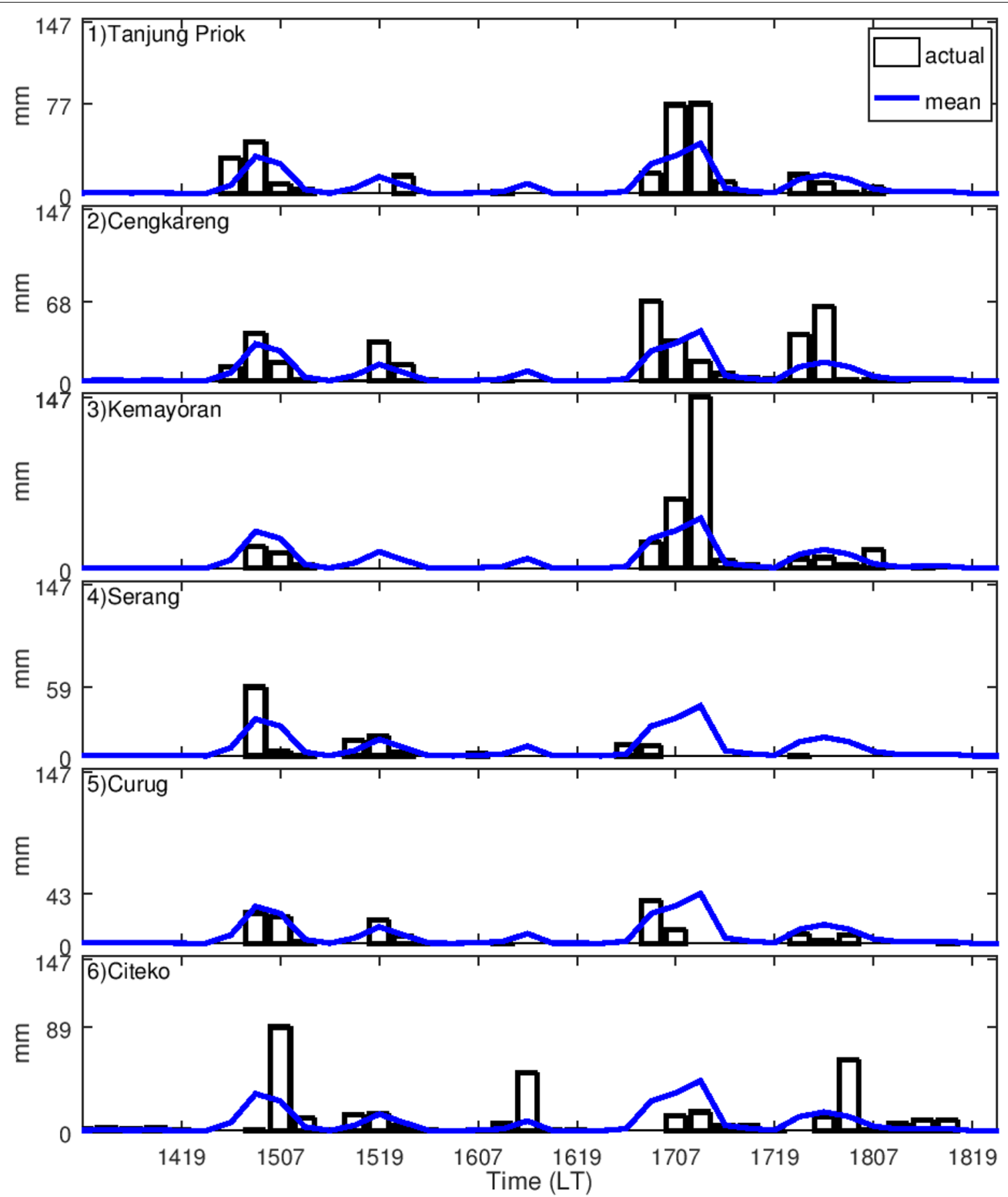

Fig. 3 Time-series of 3 hourly rainfalls from 6 weather stations (bar) and stations averaged (line) during 14-18 January 2013. Horizontal label is date and hour, for example, 1419 denotes 19:00 LT on January 14th, 2013 
The atmospheric condition in Cengkareng about $3 \mathrm{~h}$ before the emergence of first MCS (January 15, 2013) and $7 \mathrm{~h}$ before second MCS (January 17, 2013) indicated conditional instability for a surface air mass showing CAPE

Table 3 Environmental CAPE and CIN ahead of both the first and the second MCSs obtained from Cengkareng, Soekarno Hatta International Airport sounding data

\begin{tabular}{lll}
\hline & First MCS & Second MCS \\
\hline Time of sounding & 14 January 2013 & 16 January 2013 19:00 LT \\
LCL & $19: 00 \mathrm{LT}$ & \\
$\mathrm{LFC}$ & $964.1 \mathrm{hPa}$ & $966.5 \mathrm{hPa}$ \\
$\mathrm{EL}$ & $900.5 \mathrm{hPa}$ & $919.4 \mathrm{hPa}$ \\
$\mathrm{CAPE}$ & $123.0 \mathrm{hPa}$ & $119.4 \mathrm{hPa}$ \\
$\mathrm{CIN}$ & $2920.2 \mathrm{~J} / \mathrm{kg}$ & $2888.6 \mathrm{~J} / \mathrm{kg}$ \\
Rainfall & $-19.1 \mathrm{~J} / \mathrm{kg}$ & $-15.2 \mathrm{~J} / \mathrm{kg}$ \\
\hline
\end{tabular}

The values are calculated directly from the sounding. $L C L$ is the lifting condensation level. LFC denotes a level of free convection. EL denotes the equilibrium level. CAPE denotes the convective available potential energy, while $\mathrm{CIN}$ is the convective inhibition. Early morning (01:00-07:00 LT) rainfall measure at average of six observations
2920 J with CIN 19 J and CAPE 2889 J with CIN 15 J for each MCS (Table 3). The results of the advancement of the lower layer of warm air above the sea, CAPE on first MCS are $31 \mathrm{~J}$ higher than the second MCS.

The diurnal variation of 3 hourly rainfalls in January-February within the last 15-year period (20012015) from averaging of six weather stations is shown in Fig. 4. The diurnal feature shows that rainfall greater than $6 \mathrm{~mm} / 3 \mathrm{~h}$ is generally observed throughout the day. The highest rainfall (greater than $7 \mathrm{~mm} / 3 \mathrm{~h}$ ) is indicated strongly to happen in the morning time (05:00-10:00 LT). However, during heavy rainfall events of 15-18 January 2013, most of the rainfall peaks were greater than the average of the diurnal variation, except on 16 January 2013. Additionally, the rate of intensification of precipitation during the morning in the recent decades has also been reported to have a positive trend in the climate change context (Siswanto et al. 2016).

\section{Life cycles of MCSs}

To understand the developmental stages of each MCSs, the life cycles of both MCSs will now be analyzed. Figures 5 and 6 show the horizontal distribution of the

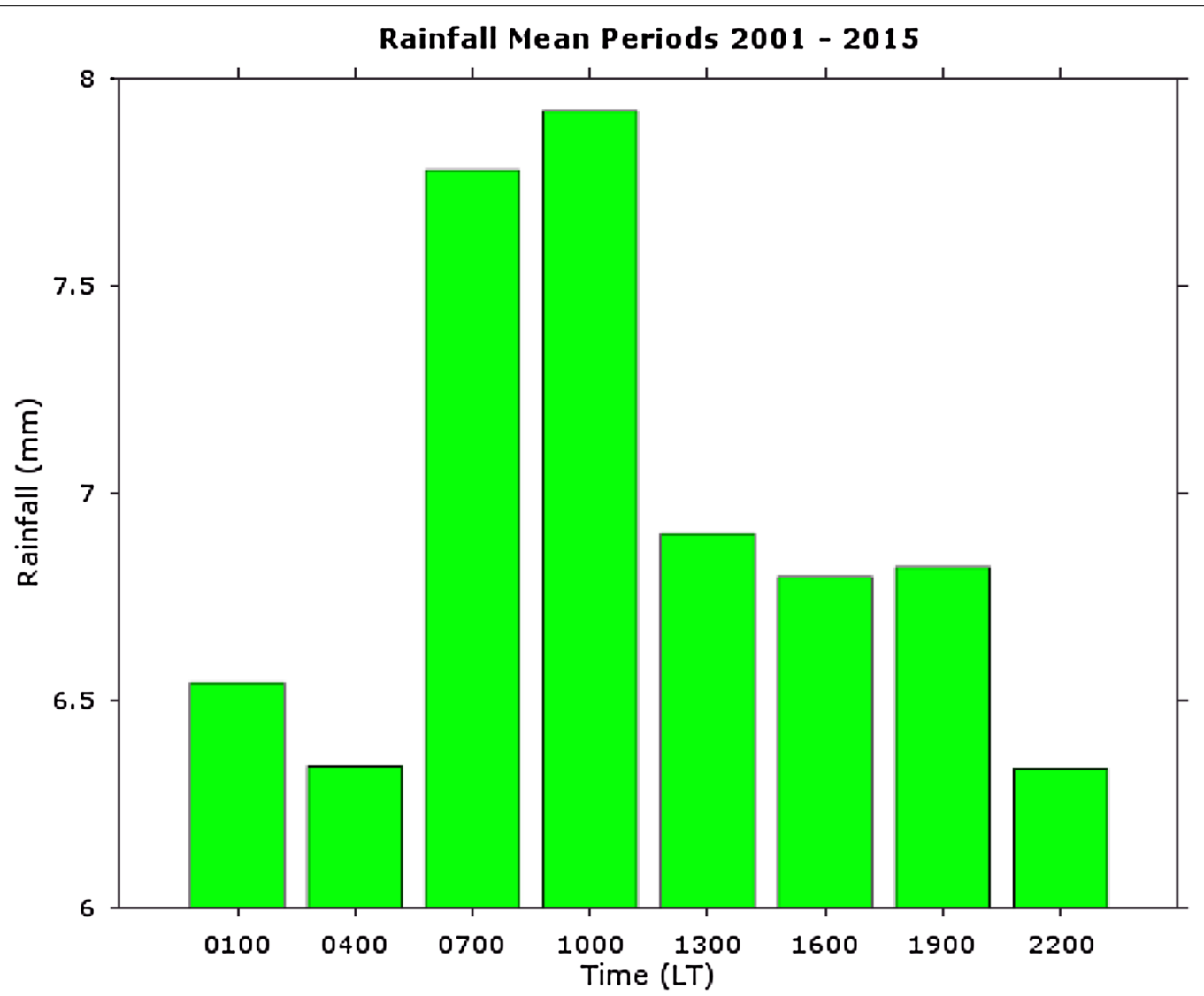

Fig. 4 The diurnal rainfall variation over January-February during 2001-2015, averaging at six weather stations over the GJ 
equivalent cloud top temperature for each MCS stage from infrared data surrounding the GJ on January 15th and 17th, respectively. The life cycle stages of MCS are analyzed following the hypothetical life cycle developing by Maddox (1980).

The first MCS began to develop at 15:00 LT on 14 January 2013 (Fig. 5a). A small-scale cloud $\left(34,538 \mathrm{~km}^{2}\right)$ was detected over the eastern coast of Sumatra. This group of cloud grew rapidly and reaching a size $\geq$ $50,000 \mathrm{~km}^{2}\left(64,188 \mathrm{~km}^{2}\right)$ after $1 \mathrm{~h}$ (Fig. 5b). By 19:00 LT (Fig. 5c), during the growth stage of MCS, the sizes of the cloud increased further and merged with each other, such that the area $\geq 50,000 \mathrm{~km}^{2}$ developed into a covered area reaching more than $100,000 \mathrm{~km}^{2}$ (Fig. 5e).
The convective cloud due to the mature stage of this MCS had area size around 222,921 $\mathrm{km}^{2}$ for the next day at 01:00 LT (Fig. 5k). Eventually, at 06:00 LT, the MCS had been identified in a dissipation stage with a size of about 104,561 km² (Fig. 5p).

At the next high precipitation event, the second MCS began to develop at 22:00 LT on 16 January 2013 (Fig. 6b). Two small-scale clouds were generated over the Java Sea and the Sunda Strait, grew slowly, merged each other and reaching the maximum sizes $\geq 50,000 \mathrm{~km}^{2}$ after $9 \mathrm{~h}$ (see Table 4). During the MCS growth (23:00-03:00 LT), the MCS merged over the Java Sea and the Sunda Strait and the cloud size increased up to $55,829 \mathrm{~km}^{2}$ at 01:00 LT (Fig. 6e). The

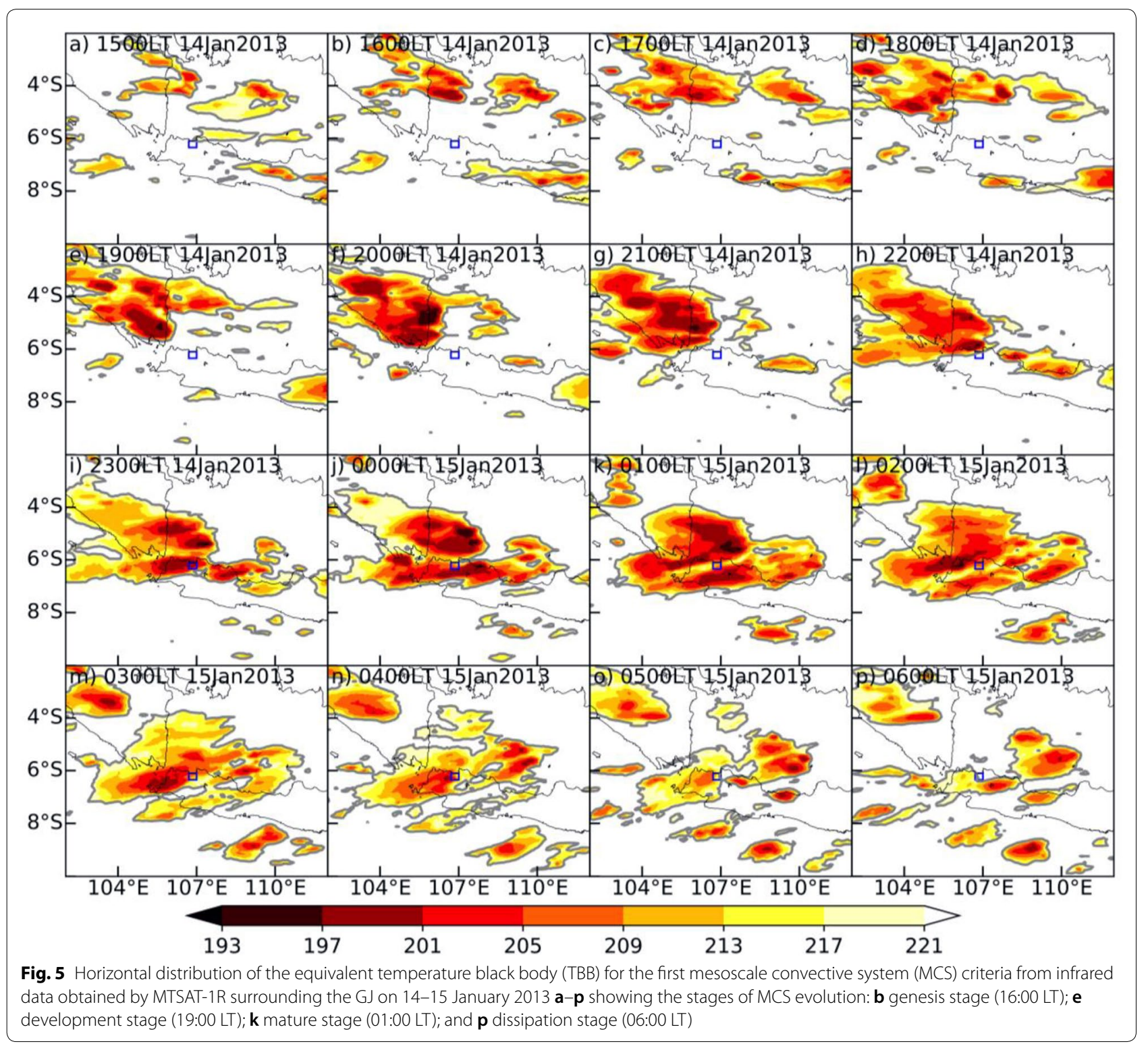




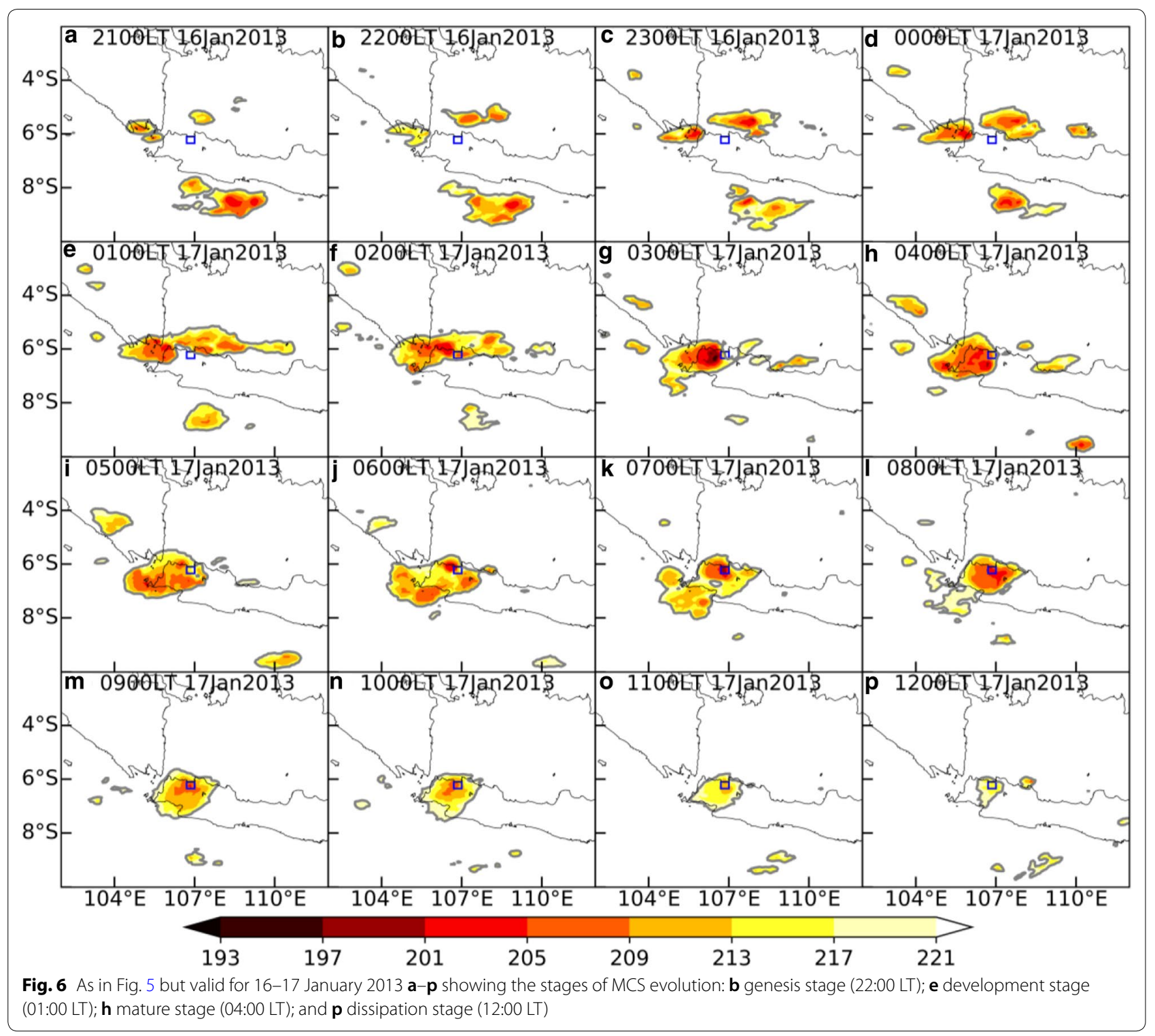

MCS reached the GJ area on 02:00 LT and then the cloud size decreased at 03:00 LT. The MCS had been identified as mature stage at 04:00 LT (Fig. 6h) with a lower minima TBB $210 \mathrm{~K}$ and an area size of $37,614 \mathrm{~km}^{2}$ (Table 4). Afterwards, the MCS began to dissipate, and the sizes start to decrease at 08:00 LT and $<35,000 \mathrm{~km}^{2}$ at 10:00 LT. Eventually, the system dissipated at 12:00 LT with the sizes of the MCS around $<10,000 \mathrm{~km}^{2}$ (Fig. 6p).

Both systems reached the mature stage in the early morning (01:00 LT and 04:00 LT), however, in the previous study conducted by Putri et al. (2017) using 2 years of data (2007-2008) most MCS in IMC achieved a maximum size at 17:00 LT. This result shows that MCS correspond to the heavy rainfall frequently occur in the early morning. Moreover, the occurrence simultaneity of the maximum intensities in both MCS events is also met by the heavy rainfall events over GJ.

\section{The mechanisms of MCS development}

The Cengkareng radar constant altitude point position indicator (CAPPI) of reflectivity displays at $2 \mathrm{~km}$ altitude from volume scans at 00:00 LT on 15 January 2013 (Fig. 7a) and 02:00 LT on 17 January 2013 (Fig. 7c) depicts the horizontal structure of MCS development in GJ. The vertical structure at dashed line crosses over GJ at 00:00 LT on 15 January 2013 (Fig. 7b) and 02:00 LT on 17 January 2013 (Fig. 7d). Vertical cross sections along 
Table 4 The MCS feature of two MCSs over the GJ

\begin{tabular}{|c|c|c|c|c|c|c|}
\hline \multirow[t]{2}{*}{ Stages } & \multicolumn{3}{|l|}{ First MCS } & \multicolumn{3}{|l|}{ Second MCS } \\
\hline & Time & Cloud size $\left(\mathrm{km}^{2}\right)$ & Mean TBB (K) & Time & Cloud size $\left(\mathbf{k m}^{2}\right)$ & Mean TBB (K) \\
\hline Initiation & 14/01/2013 16:00 LT & 64,187 & 211 & 16/01/2013 22:00 LT & 12,774 & 213 \\
\hline Development & 14/01/2013 19:00 LT & 161,730 & 211 & 17/01/2013 01:00 LT & 55,829 & 213 \\
\hline Mature & 15/01/2013 01:00 LT & 222,921 & 208 & 17/01/2013 04:00 LT & 37,614 & 210 \\
\hline Termination & 15/01/2013 06:00 LT & 104,561 & 213 & 17/01/2013 12:00 LT & 9304 & 218 \\
\hline
\end{tabular}

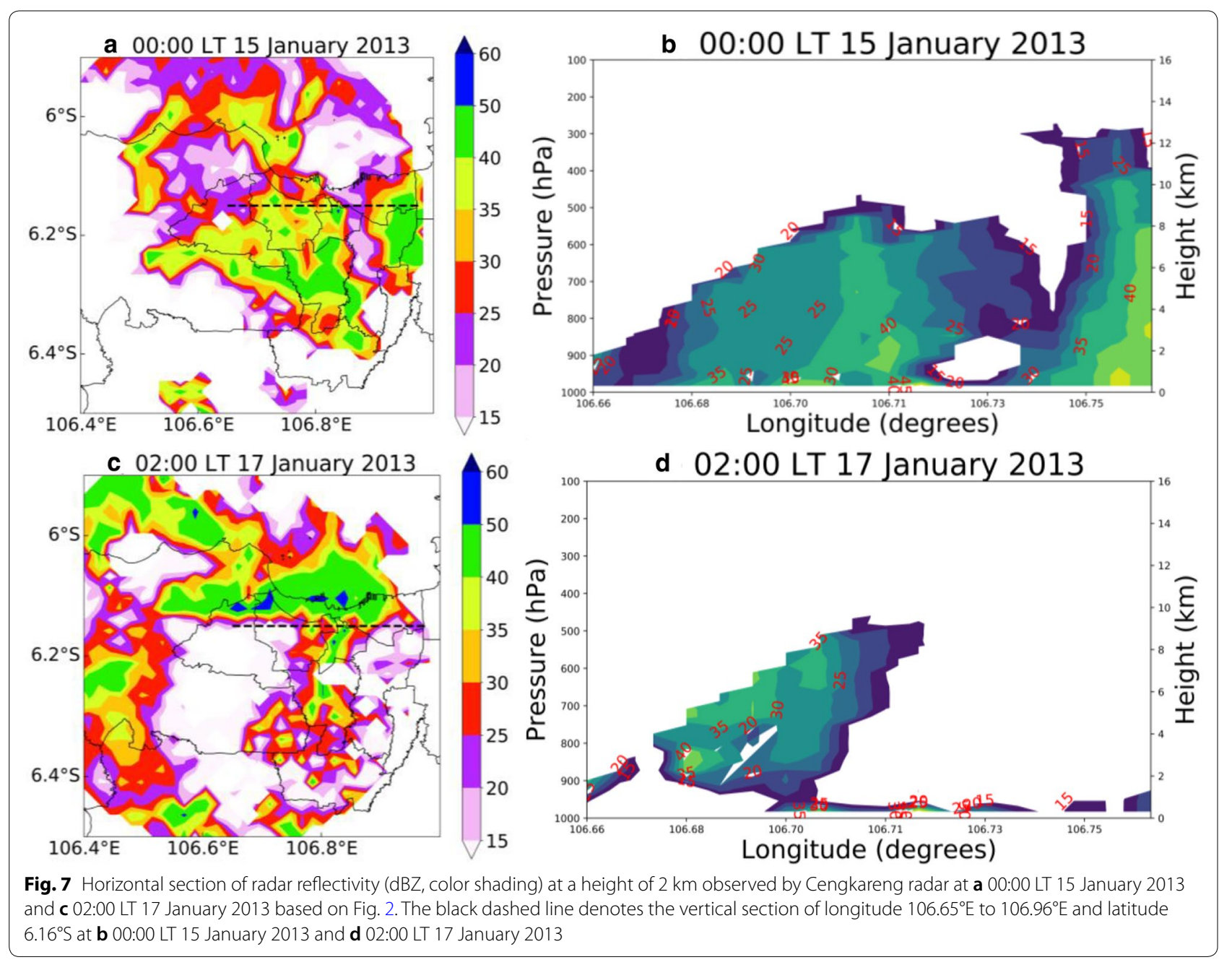

the west-east-oriented convective line depict the characteristics of the different process. The environment in the first MCS obviously active earlier than others.

Figure 8 shows the composite of TBB for the first MCS during early morning 01:00-04:00 LT 15 January 2013. The MCS extended covered area from Lampung to West Java including part of the Indian Ocean and Java Sea. The surface wind perturbation indicates the wind convergence around the Java Sea in which it might support the development of the MCS over the GJ area since 01:00
LT on 15 January 2013. Respectively, the southwesterly and northerly surface wind perturbation from the Indian Ocean and South China Sea trough Java Sea also indicated the activity of the large-scale airflow patterns, such as Asian winter monsoon (December-January-February). Both southwesterly and northerly winds might be persistently transported the high equivalent potential temperature air from the Indian Ocean and South China Sea to the GJ area. 


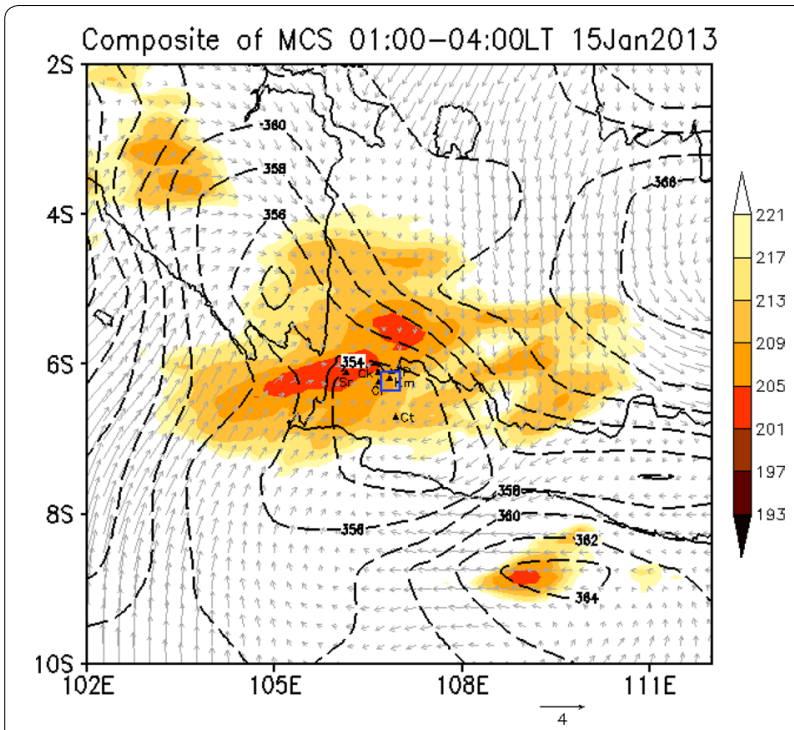

Fig. 8 Horizontal distribution of TBB composite ( $K$, shaded), surface wind vector perturbation ( $\mathrm{m} \mathrm{s}^{-1}$, vector), and surface equivalent potential temperature ( $K$, contour). For the first MCS TBB composite period 01:00-04:00 LT 15 January 2013, while surface wind vector perturbation and surface equivalent potential temperature at 01:00 LT 15 January 2013. The blue rectangle denotes the study area $\left(106.7^{\circ} \mathrm{E}-107.0^{\circ} \mathrm{E}\right.$ and $\left.6.10^{\circ} \mathrm{S}-6.35^{\circ} \mathrm{S}\right)$

Figure 9 shows the composite for the second MCS event at morning during 04:00-08:00 LT 17 January 2013. The second MCS provided the smaller convective system covering the West Java region, including the part of the Indian Ocean. The northeasterly surface wind also indicated the stronger activity of the large-scale monsoonal patterns from the Java Sea brought moisten air intensifying cloud system over West Java.

However, surface equivalent potential temperature in the MCS active convection area is lower than other regions. Strong northeasterly surface wind flew from the Java Sea brought the moist air through West Java. It met with the southeasterly surface wind to become convergence area. Both events also showing moist air flows from the Indian Ocean is propagated southwesterly and southeasterly for the first and second MCSs, respectively. In this case, the water vapor that gathers above the Indian Ocean and Java Sea moves to GJ and its surroundings. Weak wind perturbations provide greater convective cloud area than at strong wind perturbations.

The vertical structure of the tropospheric layer above the GJ is displayed in Fig. 10. The profile of mixed layer deep of potential temperature is not seen in both MCSs, indicating a stable atmosphere in about $19 \mathrm{~km}$ away from Central Jakarta. However, a higher potential temperature appeared from $700-$ to $500-\mathrm{hPa}$ (line

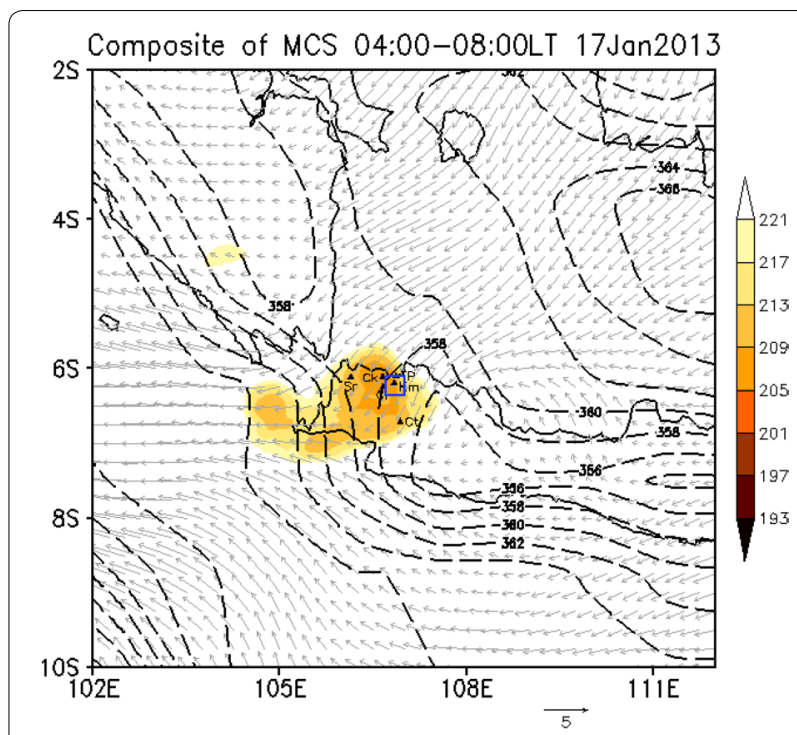

Fig. 9 As in Fig. 8 but valid for the second MCS. The TBB composite periods are at 04:00-08:00 LT 17 January 2013, while surface wind vector perturbation and surface equivalent potential temperature are at 07:00 LT 17 January 2013

curve) prior the second MCS (Fig. 10a). Warmer air was collected at this layer. Between $700-$ and $500-\mathrm{hPa}$, the mixing ratio is smaller in the second MCS than the first one (Fig. 10b). The vertical distribution of equivalent potential temperatures (Fig. 10c) shows that the stratification of middle atmosphere between 700- and $550-\mathrm{hPa}$ is unstable for moist convection in the first MCS and neutral in the second MCS. The near surface layer from 900 - to $700-\mathrm{hPa}$, however, is showing a nearly neutral and unstable for moist convection in the first and second MCSs, respectively. The vertical wind shear in the second MCS is weaker compared to the first MCS (Fig. 10d). The wind speed at the lower levels is weaker in the second MCS $(\sim 12 \mathrm{~m} / \mathrm{s})$ than in the first MCS $(\sim 15 \mathrm{~m} / \mathrm{s})$, but high in location. The strong lowlevel wind speed supports convergence and triggers the deep convection by enhancing warm advection around the GJ. The strongest wind speed is representing the large MCS because of the strong wind speed enhances warm advection to deep convection.

The fact of a higher equivalent potential temperature between $900-$ and $700-\mathrm{hPa}$ layers in the second MCS might give an extensive source of moist air. In the other words, both surface strong wind perturbation and equivalent potential temperature in the second MCS could be attributed to higher precipitation over the GJ compared with the first one. A higher of positive equivalent potential temperature advection is naturally positioned adjacent the rainfall maximum (Junker et al. 1999). 

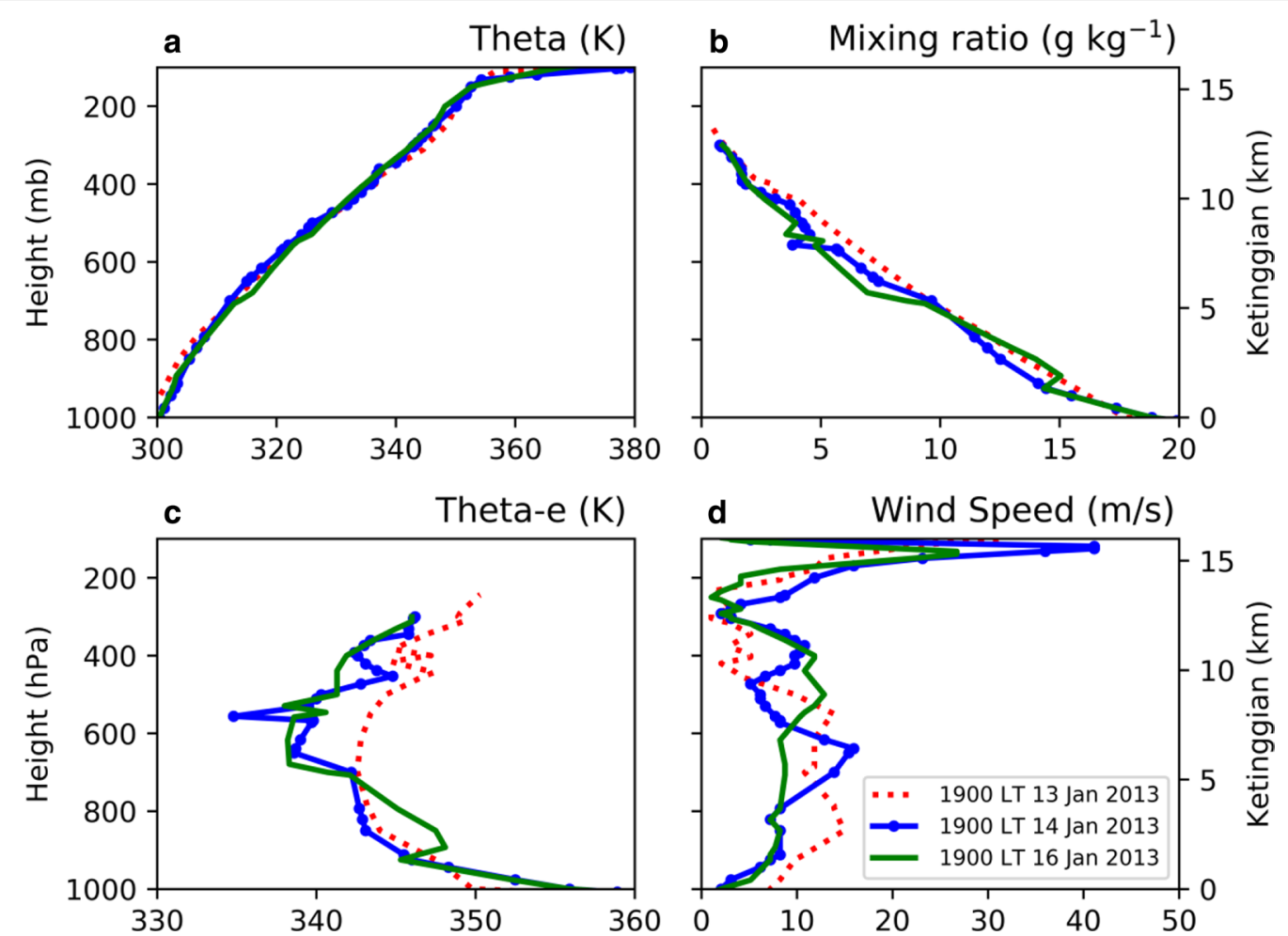

Fig. 10 Profile of a potential temperature (theta, K), b mixing ratio $(\mathrm{g} / \mathrm{kg})$, c equivalent potential temperature (theta-e, K), and $\mathbf{d}$ horizontal wind speed $(\mathrm{m} / \mathrm{s})$ from upper-air sounding observation at Cengkareng during evening (19:00 LT) prior of MCS events. The dotted curve denotes the atmospheric condition of no-MCS event, the dotted line curve indicates the atmospheric condition first MCS event and the line curve shows the atmospheric condition of next MCS event

It is clear that the specific atmospheric conditions (wind convergence and moisture flux) around the study area influence the MCS development. However, these parameters do not guarantee that there would be support for the convection processes. They are part of the larger scale circulation, i.e., strong monsoonal flow (Wu et al. 2007, Trilaksono et al. 2011, 2012; Siswanto et al. 2015), strong MJO (Hidayat and Kizu 2010; Hattori et al. 2011; Wu et al. 2013) and normal ENSO (ONI $=-0.4)$, also supporting the convection development.

\section{Environmental condition of two significant MCSs (15 and 17 January 2013)}

Figure 11 shows the surface, $925-\mathrm{hPa}$ and $850-\mathrm{hPa}$ level atmospheric condition at 01:00 LT on 15 January 2013, at approximately the occurrence time of the first MCS preceding the initial time of heavy rainfall over the GJ. The JRA55 wind and pressure reanalysis on 15 January at 01:00 LT indicates that at the near surface the GJ was on the edge between a high and low-pressure system (Fig. 11a). The GJ is on the tongue shape of a high pressure (1010-hPa) extended southeastward. The strong low-level wind flow also appeared along the South China Sea and Indian Ocean towards the Java Island.

Figure $11 \mathrm{~b}$ describes the negative temperature advection that shows a cold surge event. Negative temperature advection spread southward to the equator, indicating the presence of the northerly cold surge. The negative temperature advection shows that lower values of temperature are being advected towards higher values. The end result of negative advection is to decrease the temperature values in the direction the wind is blowing. The cold surges may also enhance the convective activity during the monsoon season by convergence wind with land breezes from the northwest of Borneo (Houze et al. 1981; Johnson and Priegnitz 1981; Johnson and Kriete 1982). The cold surges may be strengthened the Asian winter monsoon flow from north of the equator towards the IMC including the GJ area.

Figure $11 \mathrm{c}$ indicates the temperature advection of about $10 * 10^{-5} \mathrm{Ks}^{-1}$, maximum at around Southern Sumatra towards the southeast direction at the level 850-hPa during the first MCS development at 01:00 LT 15 January 2013, in association with the northeasterly 

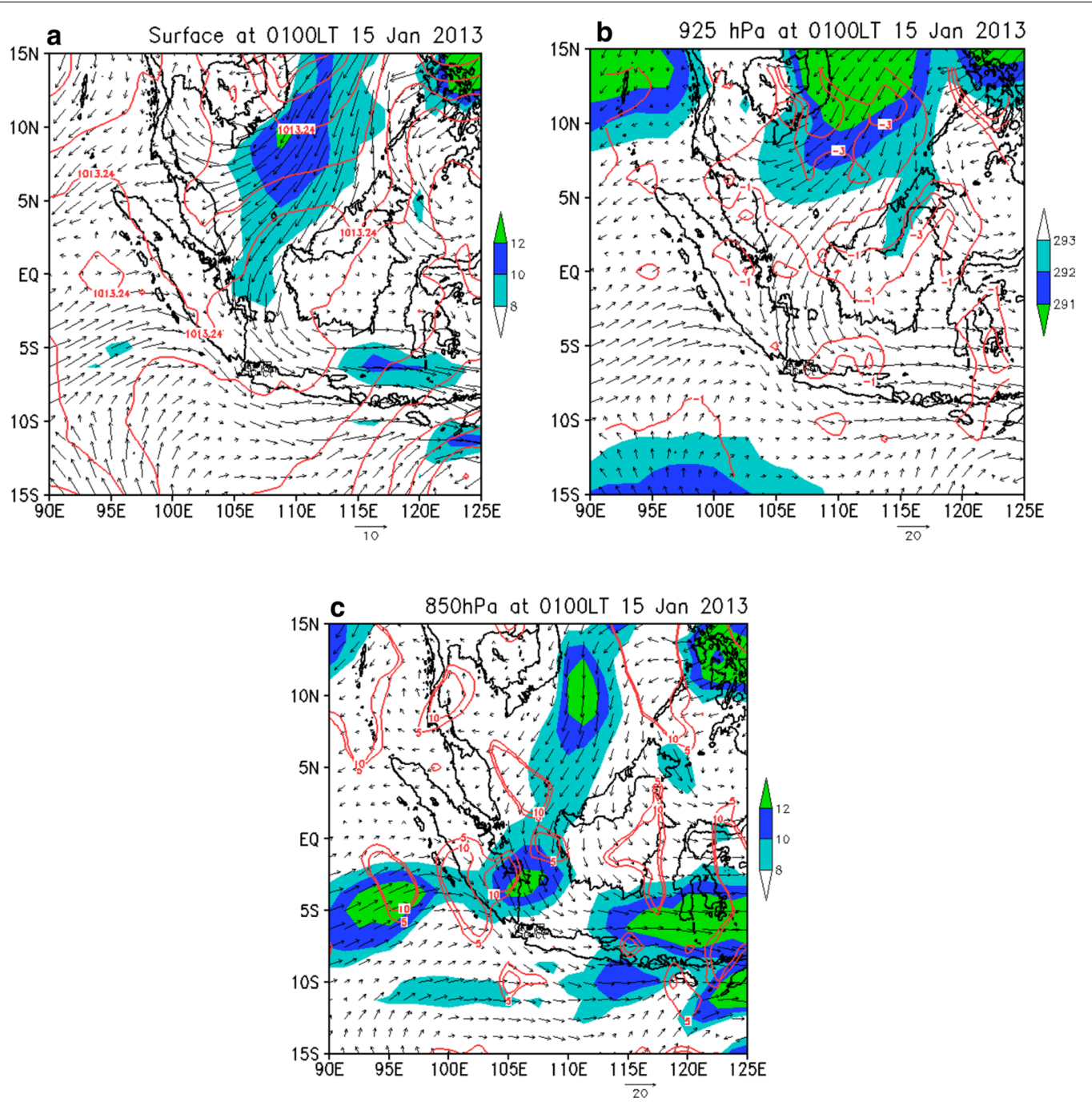

Fig. 11 JRA55 reanalysis of a horizontal wind vectors ( $\mathrm{ms}^{-1}$, speed also shaded) and pressure ( $\mathrm{hPa}$, contours) at mean sea level, $\mathbf{b}$ horizontal wind vectors $\left(\mathrm{ms}^{-1}\right)$, air temperature ( $\mathrm{K}$, shaded), temperature advection $\left(10^{-5} \mathrm{Ks}^{-1}\right.$, contours) at $925-\mathrm{hPa}$ and $\mathbf{c}$ horizontal wind vectors (ms ${ }^{-1}$, shaded), temperature advection $\left(10^{-5} \mathrm{Ks}^{-1}\right.$, contours) at 850 -hPa during the first MCS event

wind with a speed of more than $10 \mathrm{~ms}^{-1}$ across the GJ. The positive temperature advection resulted a warm and moist air that is generated by the low-level convergence. The strong low-level winds deliver moisture-laden air from the South China Sea and Indian Ocean towards the Java Island and support the development of the first MCS over the GJ.

Similarly, for the second MCS event on 17 January 2013, the high-pressure tongue shape, again appeared and reached the GJ with pressure gradient up to $2 \mathrm{hPa}$ lower than that to the north (Fig. 12a). Love (1985) showed that the zonal pressure gradients near the equator induced by cold surges enhanced low-level convergence into the inter-tropical convergence zone increases convection. Figure $12 \mathrm{~b}$ denotes that temperature advection with similar values as the previous event is detected maximum at around West Java east of the GJ. This is still associated with the strong low-level wind convergence in South China Sea and Indian Ocean towards the Java Island, although the wind appears lower speed than the previous event. Figure $12 \mathrm{c}$ also shows the negative temperature advection reaching the Karimata Strait that shows a cold surge event.

The cold surge can carry a low-level air mass from the mid-latitudes to the equator pretty well. As this cold and dry air mass moves into low latitudes, strong shallow heat fluxes weaken the cold air anomalies, and the flow may lose its cold character. However, strong meridional winds remain as clear marks of the surge. This feature is essential for the development of MCSs over the tropical 

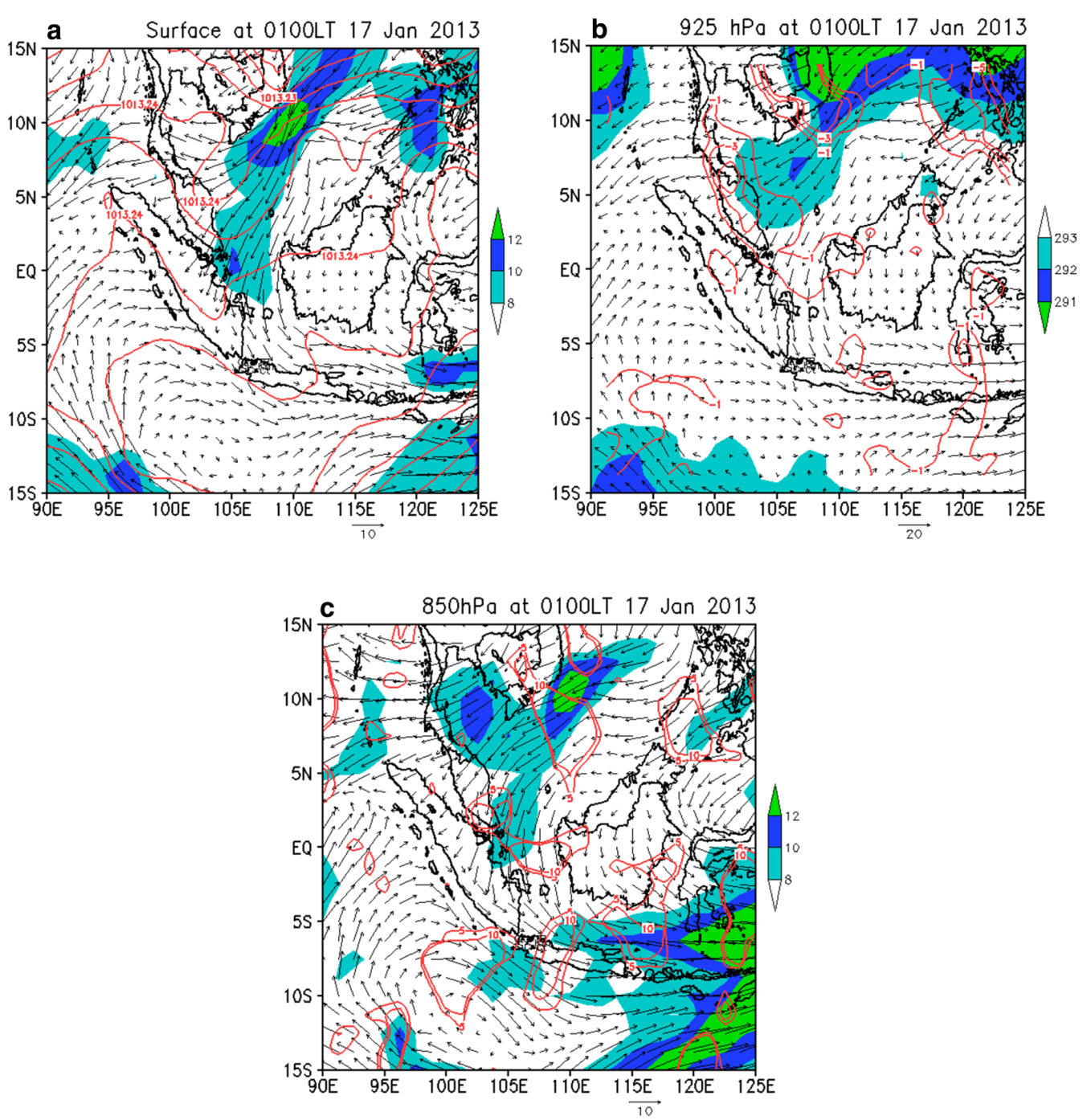

Fig. 12 As in Fig. 11 but valid for the second MCS event

region. In this study, a cold surge is coming from mid-latitude. Because of convergence wind around South Sumatra and Karimata Strait (positive temperature advection), the moist air was increased. The advection at $850 \mathrm{hPa}$ resulted a warm and moist air by low-level convergence. Cold surge's impact on MCSs is primarily driven by wind-terrain interaction: convergence produced by strong onshore winds against topography over Sumatra and Java.

The first report on the same event has been done by Wu et al. (2013). They have already shown sea surface wind measured by WindSat satellite for 17 January 2013, radiosonde data (a time-vertical wind plot based on vertical profiles), and large-scale wind distribution (a satellite-observed wind vectors corresponding to objective analyses). They have pointed out the effects of intraseasonal variation (MJO) from the Indian Ocean (as mentioned in "The mechanisms of MCS development" and "Environmental condition of two significant MCSs (15 and 17 January 2013)" subsections), as well as those of cold surge as mentioned in "Environmental condition of two significant MCSs (15 and 17 January 2013)" subsections or monsoons in "The mechanisms of MCS development" subsections. The cold surge and its modification such as vortex formation near Borneo (for general cases including this case) have been studied also by (Chen et al. 2017; Matsumoto et al. 2017). Additionally, MCSs deliver a broad range of severe convective weather events (Houze et al. 1990; Doswell et al. 1996; Jirak et al. 2003) that are potentially flooding urban area. 


\section{Conclusion and recommendations}

We have examined the MCSs which associated with heavy rainfall of on the GJ area during periods 15-18 January 2013. The major finding of this study lies on the fact that certain MCS modulated the heavy rainfall significantly. A significant feature during the period between initiation and termination of heavy rainfall in the GJ area is indicating the contribution of two MCS developments. Both the surface strong wind perturbation and the equivalent potential temperature might be influenced to heavy rainfall over the GJ in the second than the first MCS.

The results obtained here clearly explain the atmospheric conditions, such as low-level wind convergence and equivalent potential temperature, influence the MCS development. This study proved that the MCS had different processes in their mature stage. On the low-level layers in the evening prior the second MCS, appeared warmer and more moist air than the first event. The wind speed at the lower levels was stronger in the first MCS $(\sim 15 \mathrm{~m} / \mathrm{s})$ than in the second MCS $(\sim 12 \mathrm{~m} / \mathrm{s})$ that causes larger MCS in the first MCS.

\begin{abstract}
Abbreviations
MCS: mesoscale convective system; GJ: Greater Jakarta; IMC: Indonesia Maritime Continent; MJO: Madden-Julian Oscillation; TBB: temperature black body; MTSAT: Multi-functional Transport Satellite; IR: infrared; RISH: Research Institute for Sustainable Humanosphere; CCMP: cross-calibrated multi-platform; JRA-55: Japanese Reanalysis 55 Years; JRA-25: Japanese Reanalysis 25 Years; NCEP: National Centers for Environmental Prediction; NCAR: National Center for Atmospheric Research; CFSR: Climate Forecast System Reanalysis; GTG: Grab 'em, Tag 'em, Graph 'em; LT: local time; ONI: Oceanic Nino Index.
\end{abstract}

\section{Authors' contributions}

DEN conducted data processing and analysis, and drafted the manuscript; HP provided insight into this MCS case based on analysis of observation data; $\mathrm{RH}$ helped with the additional analysis; EA provides insight into the significant content of the manuscript. All the authors joined the discussion on the results. All authors read and approved the final manuscript.

\section{Author details \\ ${ }^{1}$ Department of Geophysics and Meteorology, Bogor Agricultural University, Kampus IPB Darmaga, Bogor 16680, Indonesia. ${ }^{2}$ Research and Development Center, Indonesian Agency for Meteorology Climatology and Geophysics, Jl. Angkasa I No. 2 Lt. 8, Kemayoran, Jakarta Pusat 10720, Indonesia. ${ }^{3}$ Agency for the Assessment and Application of Technology, Jl MH Thamrin No 8, Jakarta 10340, Indonesia.}

\section{Acknowledgements}

The authors thank Siswanto, whose outstanding efforts were critical to helpful advices on the manuscript. This research was part of a study at the Graduate Study Program in Applied Climatology_Department of Geophysics and Meteorology, Bogor Agricultural University and financially supported by the Indonesian Agency for Meteorology Climatology and Geophysics (BMKG).

\section{Competing interests}

The authors declare that they have no competing interests.

\section{Availability of data and materials}

The datasets generated and analyzed during the current study are available from the corresponding author upon reasonable request. Please contact the corresponding author for data requests.

\section{Funding}

This study financially support under Contract HK.401/15/RO.3/I/2018 was provided by the Indonesian Agency for Meteorology Climatology and Geophysics (BMKG).

\section{Publisher's Note}

Springer Nature remains neutral with regard to jurisdictional claims in published maps and institutional affiliations.

Received: 9 August 2018 Accepted: 16 February 2019

Published online: 26 February 2019

\section{References}

Atlas R, Hoffman RN, Ardizzone J et al (2011) A cross-calibrated, multiplatform ocean surface wind velocity product for meteorological and oceanographic applications. Bull Am Meteorol Soc 92:157-174. https://doi. org/10.1175/2010BAMS2946.1

Chen T-C, Tsay J-D, Matsumoto J, Alpert J (2017) Forecast advisory for a cold-season heavy rainfall/flood event that developed from multiple interactions of the cold-surge vortex with cold-surge flows in the South China Sea. Weather Forecast 32:797-819. https://doi.org/10.1175/ WAF-D-16-0148.1

Choi HY, Ha JH, Lee DK, Kuo YH (2011) Analysis and simulation of mesoscale convective systems accompanying heavy rainfall: the goyang case. Asia Pacific J Atmos Sci 47:265-279. https://doi.org/10.1007/s1314 3-011-0015-x

Doswell CA, Brooks HE, Maddox RA (1996) Flash flood forecasting: an ingredients-based methodology. Weather Forecast 11:560-581. https:// doi.org/10.1175/1520-0434(1996)011\%3c0560:FFFAIB\%3e2.0.CO;2

Hamada A, Nishi N (2010) Development of a cloud-top height estimation method by geostationary satellite split-window measurements trained with CloudSat Data. J Appl Meteorol Climatol 49:2035-2049. https://doi. org/10.1175/2010JAMC2287.1

Harada Y, Kamahori H, Kobayashi C et al (2016) The JRA-55 Reanalysis: representation of atmospheric circulation and climate variability. J Meteorol Soc Japan 94:269-302. https://doi.org/10.2151/jmsj.2016-015

Hattori M, Mori S, Matsumoto J (2011) The cross-equatorial northerly surge over the maritime continent and its relationship to precipitation patterns. J Meteorol Soc Japan 89A:27-47. https://doi.org/10.2151/jmsj.2011-A02

Hidayat R, Kizu S (2010) Influence of the Madden-Julian Oscillation on Indonesian rainfall variability in austral summer. Int J Climatol 30:1816-1825. https://doi.org/10.1002/joc.2005

Houze RAJ (2014) Cloud Dynamics, Second Edi. Academic Press, Amsterdam Houze RAJ, Geotis SG, Marks FD Jr, West AK (1981) Winter monsoon convection in the vicinity of North Borneo. Part 1: structure and time variation of the clouds and precipitation. Mon Weather Rev 109:1595-1614

Houze RAJ, Smull BF, Dodge P (1990) Mesoscale organization of springtime rainstorms in Oklahoma. Mon Weather Rev 118:613-654

Jeong J-H, Lee D-I, Wang C-C, Han I-S (2016) Characteristics of mesoscaleconvective-system-produced extreme rainfall over southeastern South Korea: 7 July 2009. Nat Hazards Earth Syst Sci 16:927-939. https://doi. org/10.5194/nhess-16-927-2016

Jirak IL, Cotton WR, McAnelly RL (2003) Satellite and Radar survey of mesoscale convective system development. Mon Weather Rev 131:2428-2449. https ://doi.org/10.1175/1520-0493(2003)131\%3c2428:SARSOM\%3e2.0.CO;2

Johnson RH, Kriete DC (1982) Thermodynamic and circulation characteristics of winter monsoon tropical mesoscale convection. Mon Weather Rev 110:1898-1911

Johnson RH, Priegnitz DL (1981) Winter monsoon convection in the vicinity of north Borneo. Part 2: effects on large-scale fields. Mon Weather Rev 109:1615-1628

Junker NW, Schneider RS, Fauver SL (1999) A study of heavy rainfall events during the Great Midwest Flood of 1993. Weather Forecast 14:701-712

Kawashima M, Fujiyoshi Y, Ohi M et al (2011) Case study of an intense wind event associated with a mesoscale convective system in west Sumatera 
during the HARIMAU2006 campaign. J Meteorol Soc Japan 89A:239-257. https://doi.org/10.2151/jmsj.2011-A15

Kobayashi S, Ota Y, Harada Y et al (2015) The JRA-55 reanalysis: general specifications and basic characteristics. J Meteorol Soc Japan 93:5-48

Love G (1985) Cross-equatorial interactions during tropical cyclogenesis. Mon Weather Rev 113:1499-1509

Maddox RA (1980) Mesoscale convective complexes. Bull Am Meteorol Soc 61:1374-1387. https://doi.org/10.1175/1520-0477(1980)061\%3c137 4:MCC\%3e2.0.CO:2

Mathon V, Laurent H, Lebel T (2002) Mesoscale convective system rainfall in the Sahel. J Appl Meteorol 41:1081-1092. https://doi.org/10.1175/15200450(2002)041\%3c1081:MCSRIT\%3e2.0.CO;2

Matsumoto J, Wang B, Li J, et al (2017) An overview of the Asian monsoon years 2007-2012 (AMY) and multi-scale interactions in the extreme rainfall events over the Indonesian Maritime Continent. In: Chih-Pei Chang, Kuo H-C, Lau N-C, et al. (eds) The global monsoon system: research and forecast, 3rd Edition. World Scientific Publishing Co., pp 365-385

Mohr Kl, Zipser EJ (1996) Mesoscale convective systems defined by their 85-GHz ice scattering signature: size and intensity comparison over tropical oceans and continents. Mon Weather Rev 124:2417-2437

Mori S, Hamada Jl, Hattori M et al (2018) Meridional March of diurnal rainfall over Jakarta, Indonesia, observed with a C-band Doppler radar: an overview of the HARIMAU2010 campaign. Prog Earth Planet Sci 5:1-23. https ://doi.org/10.1186/s40645-018-0202-9

Nuryanto DE, Aldrian E, Pawitan H, Hidayat R (2017a) Application of graphtheory based algorithm for identifying convective complex systems over greater Jakarta basins. IOP Conf Ser Earth Environ Sci 58:012002. https:// doi.org/10.1088/1755-1315/58/1/012002

Nuryanto DE, Pawitan H, Hidayat R, Aldrian E (2017b) Propagation of convective complex systems triggering potential flooding rainfall of Greater Jakarta using satellite data. IOP Conf Series Earth Environ Sci 54:012028. https://doi.org/10.1088/1755-1315/54/1/012028

Nuryanto DE, Pawitan H, Hidayat R, Aldrian E (2018) Kinematic and thermodynamic structures of mesoscale convective systems during heavy rainfall in greater Jakarta. Makara J Sci 22:127-136. https://doi.org/10.7454/mss. v22i3.8291

Putri NS, Hayasaka T, Whitehall KD (2017) The properties of mesoscale convective systems in Indonesia detected using the Grab 'Em Tag 'Em Graph 'Em (GTG) algorithm. J Meteorol Soc Japan 95:391-409. https://doi. org/10.2151/jmsj.2017-026
Putri NS, Iwabuchi H, Hayasaka T (2018) Evolution of mesoscale convective system properties as derived from Himawari-8 high resolution data analyses. J Meteorol Soc Japan. https://doi.org/10.2151/jmsj.2018-020

Sakurai N, Murata F, Yamanaka MD et al (2005) Diurnal cycle of cloud system migration over Sumatera Island. J Meteorol Soc Japan 83:835-850. https ://doi.org/10.2151/jmsj.83.835

Siswanto S, van Oldenborgh GJ, van der Schrier G et al (2015) Trend in high-daily precipitation events in Jakarta and the flooding of January 2014. Bull Am Meteorol Soc 96:131-135. https://doi.org/10.1175/BAMSD-15-00128.1

Siswanto S, van Oldenborgh J, van der Schrier G et al (2016) Temperature, extreme precipitation, and diurnal rainfall changes in the urbanized Jakarta city during the past 130 years. Int J Climatol 36:3207-3225. https ://doi.org/10.1002/joc.4548

Trilaksono NJ, Otsuka S, Yoden S (2011) Dependence of model-simulated heavy rainfall on the horizontal resolution during the Jakarta flood event in January-February 2007. Sola 7:193-196

Trilaksono NJ, Otsuka S, Yoden S (2012) A time-lagged ensemble simulation on the modulation of precipitation over west Java in January-February 2007. Mon Weather Rev 140:601-616. https://doi.org/10.1175/MWR-D$11-00094.1$

Virts KS, Houze RAJ (2015) Variation of lightning and convective rain fraction in mesoscale convective systems of the MJO. J Atmos Sci 72:1932-1944. https://doi.org/10.1175/JAS-D-14-0201.1

Whitehall K, Mattmann CA, Jenkins G et al (2015) Exploring a graph theory based algorithm for automated identification and characterization of large mesoscale convective systems in satellite datasets. Earth Sci Informatics 8:663-675. https://doi.org/10.1007/s12145-014-0181-3

Wu P, Hara M, Fudeyasu H et al (2007) The Impact of trans-equatorial monsoon flow on the formation of repeated torrential rains over Java Island. Sola 3:93-96. https://doi.org/10.2151/sola.2007-024

Wu P, Arbain AA, Mori S et al (2013) The effects of an active phase of the Madden-Julian oscillation on the extreme precipitation event over western Java Island in January 2013. Sola 9:79-83. https://doi.org/10.2151/ sola.2013-018

Yuan J, Houze RAJ (2010) Global variability of mesoscale convective system anvil structure from A-train satellite data. J Clim 23:5864-5888. https:// doi.org/10.1175/2010JCLI3671.1

Zolman JL, Zipser EJ (2000) A comparison of tropical mesoscale convective systems in El Nino and La Nina. J Clim 13:3314-3326

\section{Submit your manuscript to a SpringerOpen ${ }^{\odot}$ journal and benefit from:}

- Convenient online submission

- Rigorous peer review

- Open access: articles freely available online

- High visibility within the field

- Retaining the copyright to your article

Submit your next manuscript at $\boldsymbol{\nabla}$ springeropen.com 